Paul De Grauwe and Yuemei Ji

\title{
Time to Change Budgetary Priorities in the Eurozone
}

With the spectre of a recession looming in the eurozone (and elsewhere), the policy question arises as to how much leeway do the fiscal authorities in the eurozone have to follow counter-cyclical fiscal policies aimed at providing some stimulus to the economy.

Paul De Grauwe, London School of Economics, UK.

Yuemei Ji, University College London, UK.
This question is important because it appears that the capacity of the European Central Bank (ECB) to provide for such a stimulus is limited. The ECB has flooded the markets with trillions of euros in liquidity (money base) since 2015. It is difficult to see how adding a couple of hundred billion euros of money base, most of which is likely to be hoarded or put to

(C) The Author(s) 2019. Open Access: This article is distributed under the terms of the Creative Commons Attribution 4.0 International License (http://creativecommons.org/licenses/by/4.0/), which permits unrestricted use, distribution, and reproduction in any medium, provided you give appropriate credit to the original author(s) and the source, provide a link to the Creative Commons license, and indicate if changes were made. 
Figure 1

Money base and money stock (M3) in the eurozone, 2007-2019

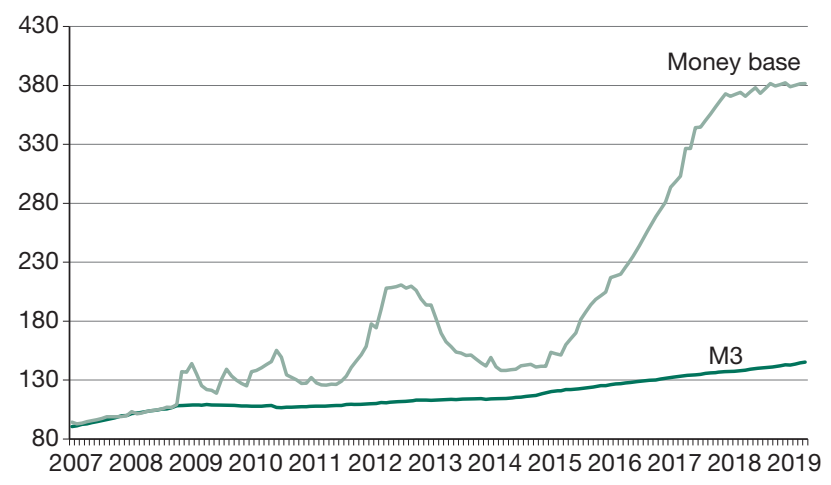

Note: $2007=100$.

Source: European Central Bank: Statistical Data Warehouse.

use for speculative activities, will provide a significant stimulus for economic activity in the eurozone.

The latter is made very clear in Figure 1. We observe that since 2015 when the ECB initiated its quantitative easing (QE) programme, the money base increased by 166 percent (from 1.2 trillion euro to 3.2 trillion euro), while at the same time the money stock increased by a mere 20 percent. This leads to the conclusion that most of the two trillion euro money base created by the ECB failed to filter through to the real economy. It is unlikely that adding more money base into the economy will change this picture significantly.

Figure 2

Interest rate regimes in selected eurozone countries, 2013-2018

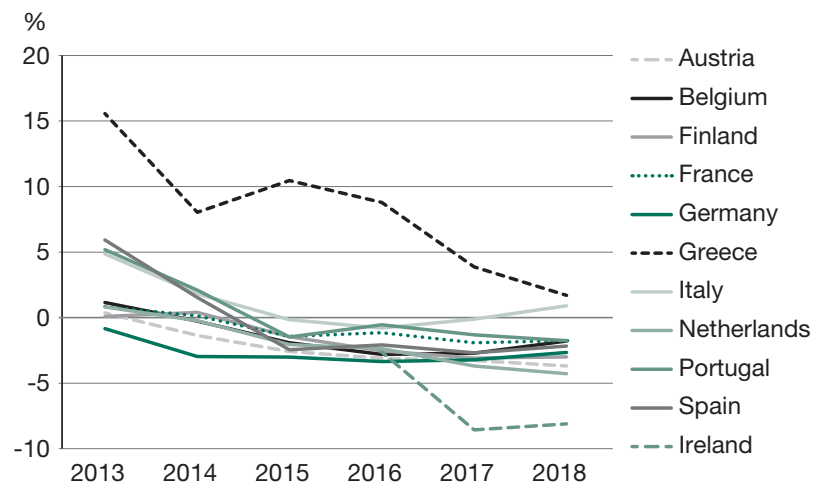

Notes: The figure shows $r-g$, where $r$ stands for the interest rate and $g$ for the growth rate of GDP; Ireland was excluded for 2015 - this was the year Ireland had a GDP growth rate exceeding $30 \%$ resulting from special accounting procedures.

Source: European Commission: AMECO database.
The preceding discussion leads to the conclusion that the burden of business cycle stabilisation in the eurozone will have to come from the fiscal authorities. The question then becomes how much leeway the fiscal authorities have to perform their stabilisation responsibilities taking into account that these authorities have significant levels of outstanding debt. There is a considerable reluctance among policymakers these days to use fiscal policies for stabilisation purposes. This reluctance is mainly driven by the fear that these policies may lead to a surge in government debt and in so doing quickly become unsustainable.

\section{Importance of interest rate regimes}

It is well known that when the nominal interest rate on the public debt exceeds the nominal growth rate of GDP, the debt-to-GDP ratio will become unstable (will grow to infinity) unless the government produces a surplus on its primary budget balance (i.e. the budget balance that excludes interest payments). It is easy to see why this is so. Suppose the primary balance is zero. This implies that the government is financing its interest spending by debt issue. This is sometimes called a Ponzi scheme. The debt will increase at a rate given by the interest rate. The GDP, however, increases at the rate given by the growth rate of GDP. This implies that the numerator in the debt-to-GDP ratio increases faster than the denominator. The only way to stop this snowball effect is to finance at least part of interest spending by taxation, i.e. by producing a surplus in the primary government balance.

Figure 3

Interest rate regimes in selected eurozone countries, 2016-2018 average

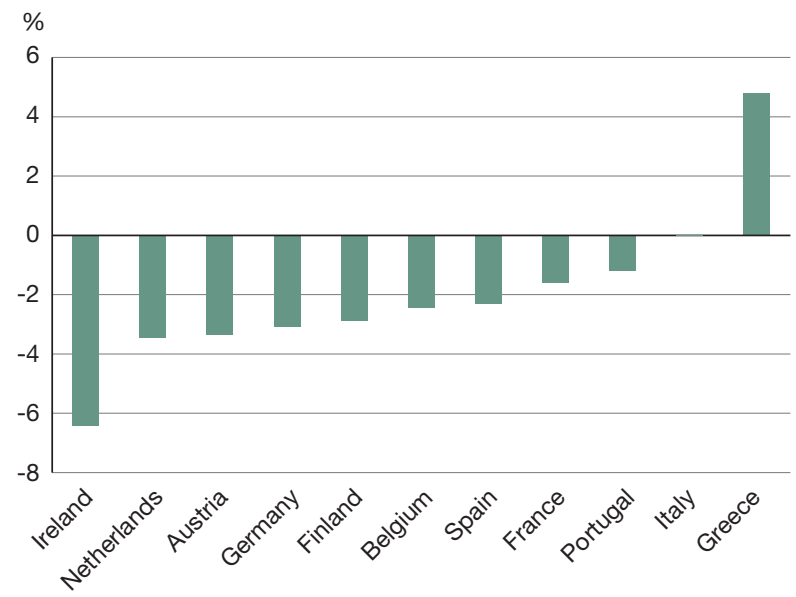

Note: The figure shows $r-g$, where $r$ stands for the interest rate and $g$ for the growth rate of GDP.

Source: European Commission: AMECO database. 
Figure 4

Interest rate regimes in selected eurozone countries, 2013-2018

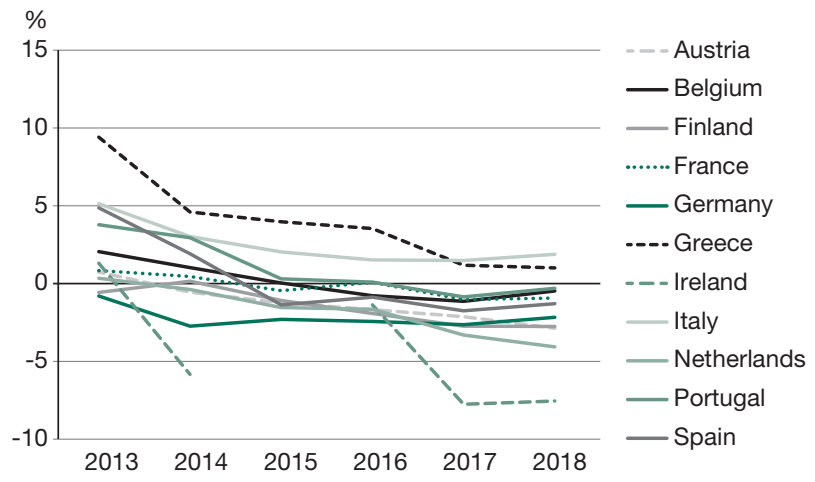

Note: The figure shows ar-g, where ar stands for the average interest rate on the existing government debt and $g$ for the growth rate of GDP; Ireland was excluded for 2015 - this was the year Ireland had a GDP growth rate exceeding $30 \%$ resulting from special accounting procedures.

Source: European Commission: AMECO database.

\section{Interest rate regimes and budget constraints}

Countries that experience an interest rate regime in which $r$ $>g$ (where $r$ is the interest rate and $g$ the growth rate of GDP) are therefore very much constrained in the use of fiscal policies. This is much less so in countries where $r<g$. In the latter countries, the inherent dynamics of the debt-to-GDP ratio will tend to be stable, i.e. even if the government finances all interest spending by debt issue, the debt-to-GDP ratio will tend to decline. There is therefore no need to produce a surplus in the primary budget balance. It is clear that in those countries facing a favourable interest rate regime, it is unnecessary for the fiscal authorities to finance interest spending by taxation. This has the effect of producing a softer budget constraint, thereby allowing for more choices in the use of fiscal policies for stabilisation purposes. ${ }^{1}$

\section{Prevailing interest rate regime in eurozone countries}

Figure 2 shows the evolution of $r$-g since 2013 (the first year after the sovereign debt crisis). We observe that $r-g$ declined in all the examined eurozone countries. The effect of this decline is that, with the exception of Greece and Italy, all analysed eurozone countries now profit from a favourable interest rate regime in which $r-g<0$. In Figure 3 , we take the average over the last three years and we come to the same con-

1 O. BIanchard: Public Debt and Low Interest Rates, Presidential Address at the American Economic Association annual meeting, 4 January 2019, available at https://www.aeaweb.org/aea/2019conference/ program/pdf/14020_paper_etZgfbDr.pdf.
Figure 5

Interest rate regimes in selected eurozone countries, 2016-2018 average

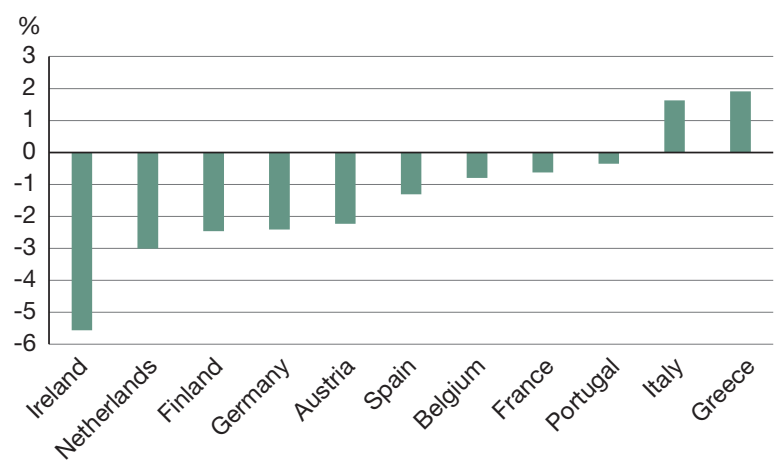

Note: The figure shows ar-g, where ar stands for the average interest rate on the existing government debt and $g$ for the growth rate of GDP.

Source: European Commission: AMECO database.

clusion, i.e. most countries of the eurozone (except Greece and Italy) have been in a favourable interest rate regime.

Figures 2 and 3 use the market rates. This measures the marginal cost of issuing debt. The latter may diverge from the average interest cost of the government debt. Therefore, we made the same calculations using the average interest cost. The results, shown in Figures 4 and 5, turn out to be similar to the ones we obtained using the market rate.

\section{Policy choices and sustainability of government debt}

We perform an analysis of the policy choices and the sustainability of the government debt using a behavioural macroeconomic model as developed by De Grauwe and De Grauwe, Foresti and $\mathrm{Ji}^{2}{ }^{2}$ This is a model that produces booms and busts in economic activity endogenously and that, therefore, seems to be appropriate to analyse the effectiveness and the trade-offs that authorities face when confronted with the dynamics of booms and busts.

\section{Behavioural macroeconomic model}

In contrast with the existing dynamic stochastic general equilibrium (DSGE) models based on rational expectations,

2 P. De Grauwe: Lectures on Behavioral Macroeconomics, 2012, Princeton University Press; P. De Grauwe, P. Foresti, Y. Ji: Fisca Policies in Booms and Busts, CEPR Discussion Paper No. DP13740, 2019, available at https://ssrn.com/abstract=3391087. 
Figure 6

Short-term fiscal multipliers under different initial conditions

Panel A: Frequency distribution of short-term fiscal multipliers

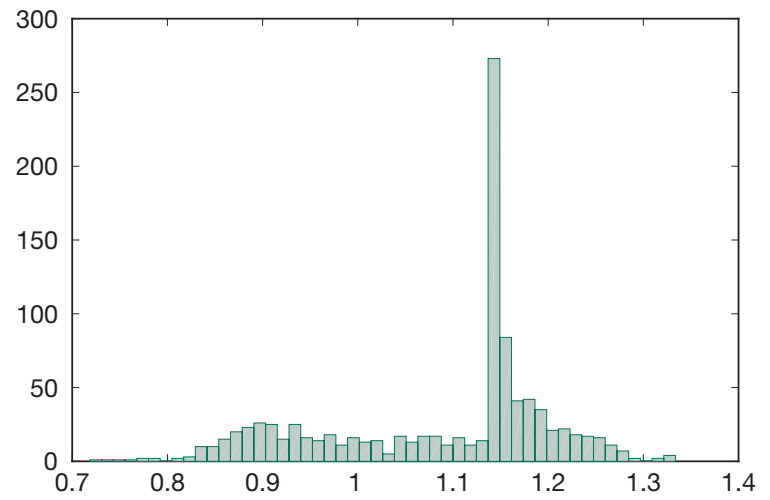

Panel B: Short-term fiscal multipliers and animal spirits

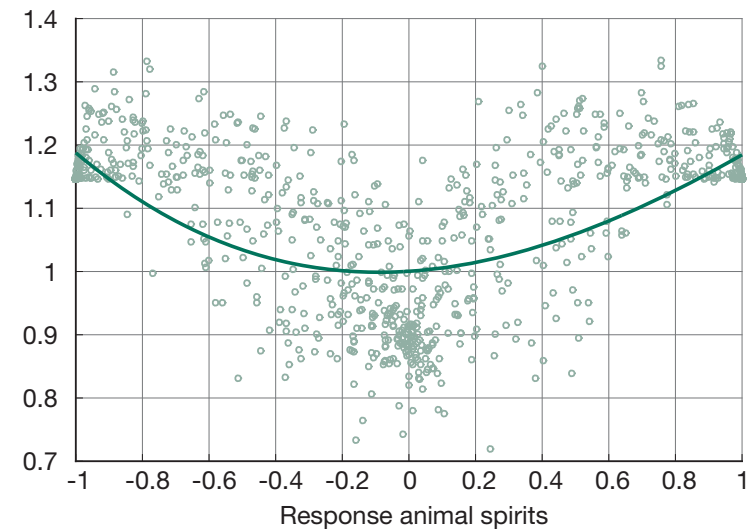

Source: P. De Grauwe, P. Foresti, Y. Ji: Fiscal Policies in Booms and Busts, CEPR Discussion Paper No. DP13740, 2019, available at https://ssrn. com/abstract $=3391087$.

our model takes the view that agents have cognitive limitations preventing them from having rational expectations. Instead, these agents use simple rules of behaviour (heuristics). The model introduces rationality by assuming that individuals learn from their mistakes and are willing to switch to the better performing rule. This model produces endogenous business cycles driven by 'animal spirits', i.e. market sentiments of optimism and pessimism that create, in a selffulfilling way, booms and busts and are influenced by these. The model also predicts that periods of tranquility alternate with booms and busts, the timing of which, however, cannot easily be predicted.

One important characteristic of this model is that the effects of policy shocks depend on the initial conditions (the state of the economy). In particular, the fiscal multipliers obtained in this model depend on the state of the economy. This is a key feature allowing us to analyse how fiscal policy can be used in different business cycle conditions.

\section{Fiscal multipliers and animal spirits}

Figure 6 shows the results of computing the fiscal multipliers in the behavioural model under different initial conditions. We simulated 1000 impulse responses of a positive government spending shock assuming different initial market sentiments (animal spirits) each time.

Panel A shows the frequency distribution of the short-term fiscal multipliers (i.e. the response of GDP after four quarters). We observe a wide variation of these multipliers, from 0.8 to 1.5 . We also note two peaks in the distribution, one around a multiplier of 1 and another around a multiplier between 1.2 and 1.3.
Panel B shows the origin of these two peaks and sets out the fiscal multipliers (vertical axis) against the state of animal spirits in the initial period. These animal spirits are expressed as an index varying between -1 and +1 . When the index equals -1 , all agents are pessimistic (i.e. forecast a decline in the output gap); when the index is +1 all agents are optimistic (i.e. forecast an increase in the output gap); when the index is 0 , optimistic and pessimistic forecasts cancel out (animal spirits are neutral).

We find that when animal spirits are neutral (tranquil periods), the fiscal multipliers cluster around 1. When animal spirits take on extreme values, these fiscal multipliers cluster around 1.2 - 1.3. Thus, extreme values of animal spirits tend to amplify the effects of a fiscal expansion and lead to multipliers exceeding 1. Note, however, that there is still a lot of noise around the non-linear relation between fiscal multipliers and animal spirits, suggesting that other initial conditions affect the size of these multipliers.

\section{Size of fiscal multipliers and the state of the economy}

There is increasing empirical support for the view that the size of the fiscal multipliers depends on the state of the economy. In a series of influential papers, Auerbach and Gorodnichenko find that the size of the fiscal multiplier (spending multiplier) is state dependent in the US economy during the post-war period. ${ }^{3}$ In particular, they find that the multiplier ex-

3 A. Auerbach, Y. Gorodnichenko: Measuring the Output Responses to Fiscal Policy, in: American Economic Journal: Economic Policy, Vol. 4, No. 2, 2012, pp. 1-27; A. Auerbach, Y. Gorodnichenko: Fiscal Multipliers in Recession and Expansion, in: A. Alesina, F. Giavazzi (eds.): Fiscal Policy after the Financial Crisis, Chicago 2013, University of Chicago Press, pp. 63-98. 
Figure 7

Trade-off between stabilisation of output and debt in different interest rate regimes

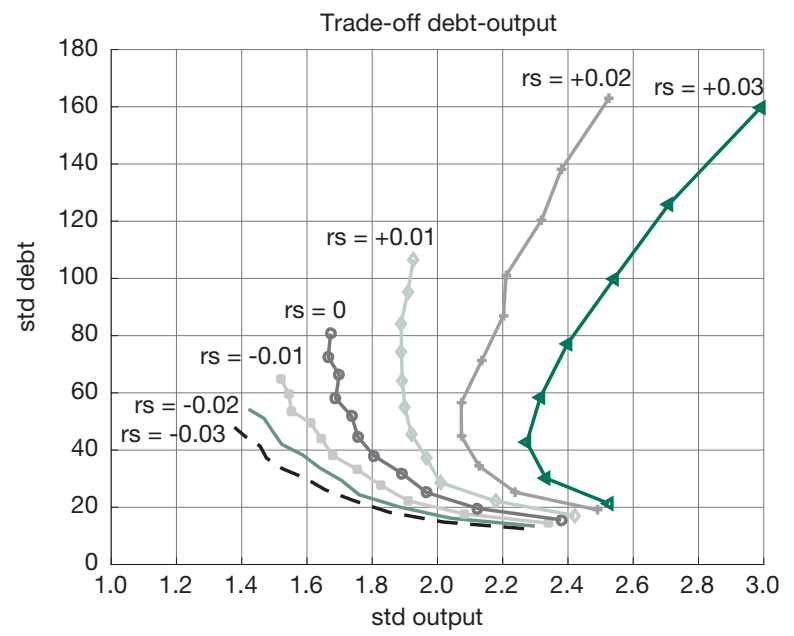

Note: The rs stands for interst rate regime with $r s=r-g$; it is assumed here that $r$ varies from $-3 \%$ to $+3 \%$.

Source: Authors' calculations.

ceeds 1 during recessions. ${ }^{4}$ It is important to have this feature in the model in order to evaluate the fiscal policy choices under different conditions of the business cycle.

\section{Trade-offs between stabilising output and debt}

The next step in the analysis is to compute the trade-offs that fiscal authorities face between stabilising output and the debt in our behavioural model, assuming that the debt is kept sustainable. As indicated earlier, this model takes into account the state of the economy when the authorities engage in counter-cyclical fiscal policies.

Figure 7 illustrates the trade-offs between the volatility of output and public debt. In order to understand these tradeoffs, we start from point $A$, which demonstrates the points of the trade-offs when there is no fiscal stabilisation, i.e. the fiscal authorities do not follow anti-cyclical policies. As they increase their anti-cyclical fiscal policies, we move up along the trade-offs.

We distinguish between different interest rate regimes, called $r s$, where $r s=r-g$. We allow $r s$ to vary from $-3 \%$ to + $3 \%$. Let us first concentrate on $r s=r-g<0$. In this regime we obtain negatively sloped trade-offs, i.e. when fiscal authorities increase their output stabilisation efforts, this comes at

4 O. Blanchard, D. Leigh: Growth Forecast Errors and Fiscal Multipliers, IMF Working Papers No. 13/1, Washington DC 2013. the price of increasing the variability of the debt. When rs = -0.03 , this negative trade-off is relatively flat, i.e. the cost of output stabilisation in terms of debt variability is small. With increasing rs, the slope of the trade-offs goes up indicating that the cost of stabilisation tends to rise.

When the interest rate regime $(r s=r-g)$ turns positive, we observe that these trade-offs tend to bend backwards. Thus, in this interest rate regime when anti-cyclical fiscal policies become strong enough, the trade-offs become positively sloped, i.e. further attempts at stabilising output by varying government spending lead to increases in both the variability of output and debt. Further attempts to use anti-cyclical fiscal policies then reduce welfare.

In order to understand this result, let us analyse what happens during a recession. In this case, the fiscal authorities increase spending in order to stabilise output. This leads to increases in the deficit and thus in government debt. We know, however, that when $r s>0$, the debt is dynamically unstable - except if the authorities keep a sufficiently positive primary balance. The anti-cyclical fiscal policy, however, leads to a departure from this condition, thereby destabilising the debt. The latter forces the fiscal authorities to reduce spending, which offsets the anti-cyclical policy stance. When rs is very positive, the underlying instability of the debt is very strong. As a result, the need to reduce spending to stabilise the debt overwhelms the anti-cyclical policy stance. Fiscal policies as a whole become pro-cyclical. Attempts to stabilise output lead to more variability of output and debt.

From the preceding it follows that in interest rate regimes in which the interest rate exceeds the growth rate of the economy, the use of fiscal policy to stabilise output is severely limited. The use of fiscal policy to stabilise the business cycle can quickly lead to a lose-lose situation in which both the government debt and the business cycle are destabilised. When the interest rate is lower than the growth rate of the economy, this problem does not arise. This is a regime that allows the fiscal authorities to follow anti-cyclical policies without destabilising government debt.

\section{Interest rate regimes in eurozone countries}

We have seen that Austria, Ireland, the Netherlands, Germany, Belgium, Spain and Finland are in an interest rate regime where $r-g$ is close to $-2 \%$ or lower. France and Portugal are also in a favourable interest rate regime, but less spectacularly so. This means that these countries face favourable trade-offs allowing them to use anti-cyclical fiscal policies without destabilising their government debts. Italy and Greece, however, do not face these favourable trade-offs and risk destabilising their government debt if they engage in intense anti-cyclical policies. 
Figure 8

\section{Primary budget balances of selected eurozone countries}

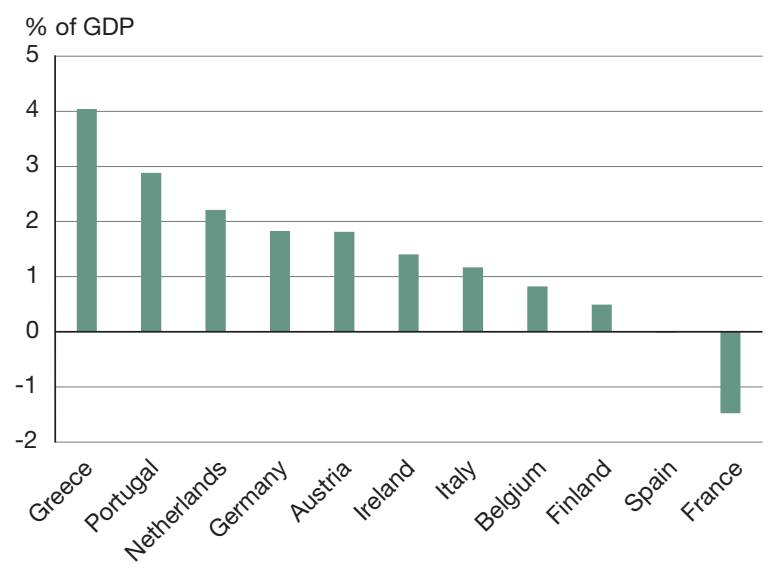

Source: European Commission: AMECO database.

We conclude that on the whole, most eurozone countries today have the capacity to use fiscal policies as a tool to fight a looming recession without the risk of destabilising their government debt levels.

\section{Changing budgetary priorities in the eurozone}

The previous conclusion can be strengthened by analysing the primary budget balances of the eurozone countries shown in Figure 8 and comparing these with the interest rate regimes shown in Figure 3. The most striking aspect of this comparison is that most eurozone countries show primary surpluses while they are in a favourable interest rate regime, i.e. $r-g<0$, although the latter would allow them to run primary deficits while keeping their debt-to-GDP ratios constant. This reflects the choice in most eurozone countries for a policy that prioritises a speedy decline in debt-to-GDP ratios. The issue is whether this policy choice continues to make sense when the eurozone economy is slowing down.

\section{Leeway for fiscal stimulus in eurozone countries}

In Table 1, we compute the primary balances that are needed for the debt-to-GDP ratios to remain constant in the eurozone countries, the results are shown in the column labelled ' $(r-g)^{\star}$ Debt'. We compare these with the observed primary balances. The difference between the two tells us how much fiscal stimulus the country could engage in while keeping its debt-to-GDP at the level reached in 2019. The results of this calculation are presented in the 'fiscal stimulus' column. These results are striking: most eurozone countries are in a situation in which they could engage in a fiscal stimulus of more than two percent of their GDP, with some countries
Table 1

Leeway for fiscal stimulus in selected eurozone countries, 2019

\begin{tabular}{lrcccc} 
Country & $\begin{array}{c}\text { Debt- } \\
\text { to-GDP } \\
\text { ratio }\end{array}$ & $\begin{array}{c}r-g \\
\text { (in \%) }\end{array}$ & $\begin{array}{c}\text { Observed } \\
(r-g)^{*} \text { Debt } \\
\text { (in \%) }\end{array}$ & $\begin{array}{c}\text { primary } \\
\text { balance } \\
\text { (in \%) }\end{array}$ & $\begin{array}{c}\text { Fiscal } \\
\text { stimulus } \\
\text { (in \%) }\end{array}$ \\
\hline Austria & 69.7 & -3.3 & -2.3 & 1.8 & 4.1 \\
\hline Belgium & 101.3 & -2.4 & -2.5 & 0.8 & 3.3 \\
\hline Finland & 58.3 & -2.9 & -1.7 & 0.5 & 2.2 \\
\hline France & 99 & -1.6 & -1.6 & -1.5 & 0.1 \\
\hline Germany & 58.4 & -3.1 & -1.8 & 1.8 & 3.6 \\
\hline Greece & 174.9 & 4.8 & 8.4 & 4.0 & -4.3 \\
\hline Ireland & 61.3 & -6.4 & -3.9 & 1.4 & 5.4 \\
\hline Italy & 133.7 & 0 & 0 & 1.2 & 1.2 \\
\hline Netherlands & 49.1 & -3.4 & -1.7 & 2.2 & 3.9 \\
\hline Portugal & 119.5 & -1.2 & -1.4 & 2.9 & 4.3 \\
\hline Spain & 96.3 & -2.3 & -2.2 & 0 & 2.2 \\
\hline
\end{tabular}

Note: The $(r-g)^{\star}$ Debt measures the primary balance that will keep the debt-to-GDP ratio at the level of 2019; the last column measures the size of the fiscal stimulus that will keep the debt-to-GDP ratio fixed at the level of 2019, given $(r-g)$ in 2019.

Source: Authors' calculations.

reaching three percent or more, while keeping their debtto-GDP ratios fixed. The exceptions are Greece, Italy and France, which have relatively little (Italy and France) or no (Greece) leeway for stimulus.

One note of warning is in place here. The numbers in the column ' $(r-g)^{\star}$ Debt' identify the necessary conditions for debt sustainability. They may not be sufficient. Take Portugal for example. The number $-1.4 \%$ says that Portugal could have a primary deficit of $1.4 \%$ that will keep the existing debt-toGDP ratio constant at the level of $119.5 \%$. That level, however, could quickly become unsustainable when some unfavourable shocks occur. Portugal, therefore, may not want to use fiscal stimulus today.

\section{Policy impliations: Fiscal stimulus is feasible}

We conclude that not all but a significant number of eurozone countries (Austria, Germany, Ireland, the Netherlands and Finland) could engage in a fiscal stimulus of three percent or more of their GDP. Given the present threat of recession, these countries should seriously consider changing their budgetary priorities, which are currently skewed towards fast reductions of their debt-to-GDP ratios, and instead prioritise a fiscal stimulus. 